\title{
Renewable Energy Home Design in Bani Walid City/Libya
}

\author{
Abdussalam Ali Ahmed* \\ PhD in Mechatronic Engineering, Mechanical and Industrial Engineering Department, Bani Waleed University, Bani Waleed, Libya
}

\author{
DOI:10.36348/SJET.2019.v04i09.002 \\ | Received: 20.08.2019| Accepted: 27.08.2019 | Published: 11.09.2019 \\ *Corresponding author: Abdussalam Ali Ahmed
}

\section{Abstract}

Although the applications of renewable energy in Libya were started in the last few decades, they have only gained momentum in the last few years. Considering the past gained experience, a proposed national Renewable Energy plan aims toward bringing RE into the main stream of the national energy supply system with a target contribution of $10 \%$ of the electricity demand by the year 2020. The aim of this paper is to design a house that works with some renewable energy applications in one of the Libyan cities called Bani Walid. This paper includes some important steps for designing a home such as solar home design steps, wind energy calculations, battery sizing, and cost considerations.

Keywords: Renewable energy, Wind energy, solar energy, Wind turbines, Solar panel.

Copyright @ 2019: This is an open-access article distributed under the terms of the Creative Commons Attribution license which permits unrestricted use, distribution, and reproduction in any medium for non-commercial use (NonCommercial, or CC-BY-NC) provided the original author and source are credited.

\section{INTRODUCTION}

Libya is a crucial country in the Middle East and North Africa; this is because it occupies a strategic location in North Africa since it is located in place of links of Southern Europe with the rest of Africa and Eastern with Western Africa. Therefore, would play a major role in connecting the oil, gas and electricity international grid. Although the fact that Libya is considered as one of the oil-rich countries, it is important to secure alternative resources of energy especially it has only one type and limited energy resources (oil). This in turn can lead to maintain oil resources for future generations and to reduce pollution.

A Solar Energy System is sometimes referred to as an Alternative Energy System. And while that's true, wind, geothermal, and hydro systems are also alternative energy sources. We focus primarily on Solar and will therefore simply use the phrase Solar Energy System or Solar Power System. To the left are the basic components required to produce electricity from the sun. You will need one or more Solar Panels, a Charger Controller, a Power Inverter, and of course, Batteries. A brief explanation on each follows. After you get an idea of the components you'll need for your solar energy system, be sure to check out our new interactive Design Tools to calculate how many solar panels and storage batteries you will need, determine battery bank wiring, and calculate proper wire sizes.

Wind energy was utilized for water pumping in many oases since 1940. The use of this energy has not been developed extensively because the wind-mills need some maintenance from time to time. In 2004 measurements of the wind speed statistics has been conducted and showed that there is a high potentiality for wind energy in Libya. The average wind speed at a 40 -meter height is between $6-7.5 \mathrm{~m} / \mathrm{s}$.

The use of wind energy for electricity production has not been started yet in Libya, but a project was contracted for installing $25 \mathrm{MW}$ as a pilot project to be erected in two years' time. A project to prepare two Atlas that provides fast access to reliable solar and wind data throughout Libya is also been contracted for. The Atlas will allow for accurate analysis of the available wind and solar resources anywhere in Libya and will be therefore very important for planning profitable wind farms and solar projects.

\section{Home appliances and consumption}

The home studied in this paper consists of two floors and tables 1 and 2 illustrate the components of each floor with the consumption of electricity for all the appliances. 
Table-1: First floor appliances

\begin{tabular}{|c|c|c|}
\hline \multicolumn{2}{|c|}{ First floor } \\
\hline 1 & Living room & Air conditioner $(1000 \mathrm{~W})+\mathrm{TV}(120 \mathrm{~W})+$ lamp lighting $(2 \mathrm{X} 60 \mathrm{~W})$ \\
\hline 2 & Dining+ kitchen & $\begin{array}{r}\text { Refrigerator }(750 \mathrm{~W})+\text { microwave }(1500 \mathrm{~W})+\text { Blender }(300 \mathrm{~W})+\text { juicer }(600 \mathrm{~W})+\text { heater } \\
(2000 \mathrm{~W})+\operatorname{lamp} \text { lighting }(2 \mathrm{X} 60 \mathrm{~W})+\text { fan }(100 \mathrm{~W})\end{array}$ \\
\hline 3 & Laundry & Washing machine $(2000 \mathrm{~W})+\operatorname{iron}(1200 \mathrm{~W})$ lamp lighting $(1 \mathrm{X} 60 \mathrm{~W})$ \\
\hline 4 & Foyer & lamp lighting $(1 \mathrm{X} 60 \mathrm{~W})$ \\
\hline 5 & Garage & lamp lighting $(1 \mathrm{X} 60 \mathrm{~W})$ \\
\hline 6 & powder & lamp lighting $(1 \mathrm{X} 60 \mathrm{~W})$ \\
\hline 7 & portico & \\
\hline
\end{tabular}

Table-2: Second floor appliances

\begin{tabular}{|c|c|c|}
\hline \multicolumn{2}{|c|}{ Second floor } \\
\hline 1 & Master room & TV $(150 \mathrm{~W})+$ Air conditioner $(1000 \mathrm{~W})+$ lamp lighting (2X60 \\
& & W)+Satellite dish $(50 \mathrm{~W})+$ CD player $(35 \mathrm{~W})$ \\
\hline 2 & Bedroom2 & lamp lighting $(1 \mathrm{X} 60 \mathrm{~W})+$ Computer PC $(150 \mathrm{~W})$ \\
\hline 3 & Bedroom 3 & lamp lighting $(1 \mathrm{X} 60 \mathrm{~W})+\mathrm{DVD}(25 \mathrm{~W})+$ stereo $(25 \mathrm{~W})+\mathrm{Kids} \mathrm{TV}(80 \mathrm{~W})$ \\
\hline 4 & Bath & Heater $(2000 \mathrm{~W})+$ hair dryer $(1100 \mathrm{~W})$ \\
\hline 5 & Hall & lamp lighting $(1 \mathrm{X} 60 \mathrm{~W})$ \\
\hline 6 & Tiled shower & Heater(2000W)+ lamp lighting $(1 \mathrm{X} 60 \mathrm{~W})$ \\
\hline
\end{tabular}

\section{Solar home design steps}

Determine the number of solar panels you will need

Calculate your electrical load. Determine the number of watt*hours your location will use on a daily basis. For an entire home, this will take some busy work.

\section{You need to determine}

- What appliances you are going to power?

- How many Watts does each appliance consume?
- On average, how many hours do you use this appliance per day? (Don't forget to include those things that you use on a weekly or monthly basis, e.g. blender).

- Calculate your average daily watt*hour usage for your entire home. That is, multiply the watts of the appliance times the average number of hours used per day.

\begin{tabular}{|c|c|c|c|c|c|}
\hline Appliance & number & $\begin{array}{c}\text { Energy } \\
\text { consumption } \\
(\mathbf{k W})\end{array}$ & Hours/day & KW-hr/day & Cost(L.D) \\
\hline Air conditioner & 2 & 2 & 10 & 20 & 0.4 \\
\hline Refrigerator & 1 & 0.75 & 24 & 18 & 0.36 \\
\hline Microwave & 1 & 1.5 & 0.5 & 0.75 & 0.015 \\
\hline Fan & 1 & 0.1 & 2 & 0.2 & 0.004 \\
\hline Washing machine & 1 & 2 & 1 & 2 & 0.04 \\
\hline Blender & 1 & 0.3 & 0.5 & 0.15 & 0.003 \\
\hline Iron & 1 & 1.2 & 0.5 & 0.6 & 0.012 \\
\hline Satellite dish & 1 & 0.05 & 8 & 0.4 & 0.008 \\
\hline CD player & 1 & 0.035 & 1 & 0.035 & 0.0007 \\
\hline Computer & 2 & 0.3 & 3 & 0.9 & 0.018 \\
\hline Kids TV & 1 & 0.08 & 3 & 0.24 & 0.0048 \\
\hline Lighting lamp & 16 DC & 0.96 & 6 & 5.76 & 0.1152 \\
\hline Stereo & 1 & 0.025 & 1 & 0.025 & 0.0005 \\
\hline Hair dryer & 1 & 1.1 & 0.5 & 0.55 & 0.022 \\
\hline TV & 1 & 0.12 & 8 & 0.96 & 0.0192 \\
\hline Juicer & 1 & 0.6 & 0.5 & 0.3 & 0.006 \\
\hline heater & 2 & 2 & 2 & 4 & 0.08 \\
\hline DVD & 1 & 0.025 & 1 & 0.025 & 0.0005 \\
\hline Total AC & & & & 49.675 & \\
\hline Total DC & & & & 5.76 & \\
\hline Total AC+DC & & & & 55.435 & \\
\hline
\end{tabular}

Determine the equivalent number of full-sun hours for your location for the month with the least amount of sunlight (December or January for Bani Walid/Libya 2018). 
Table-3: The full-sun hours for home location

\begin{tabular}{|c|c|c|c|}
\hline Month & number of full-sun hours & Month & number of full-sun hours \\
\hline January & 7.19 & July & 11.7 \\
\hline February & 8.96 & August & 11.4 \\
\hline March & 9.29 & September & 9.84 \\
\hline April & 9.41 & October & 6.62 \\
\hline May & 11.1 & November & 7.44 \\
\hline June & 11.91 & December & 6.84 \\
\hline
\end{tabular}

Divide your load calculation from step one by the number of full-sun hours from step two. This is will tell you the number of Watts of solar panels you will need to provide you enough electricity in the lowest sun-light months.

Solar Panel Watts needed: (Total Watt-hr/day)/(full sun hours/day)

Solar Panel Watts needed AC: $(49675 \mathrm{~W}-\mathrm{H} /$ day $) /(6.84$ Boulder $)=7262$ Watts

Solar Panel Watts needed DC: $(5760 \mathrm{~W}-\mathrm{H} /$ day $) /(6.84$ Boulder $)=842$ Watts

\section{Panel's selection and specifications}

In this work. The selected panels was chosen from online company website in Australia

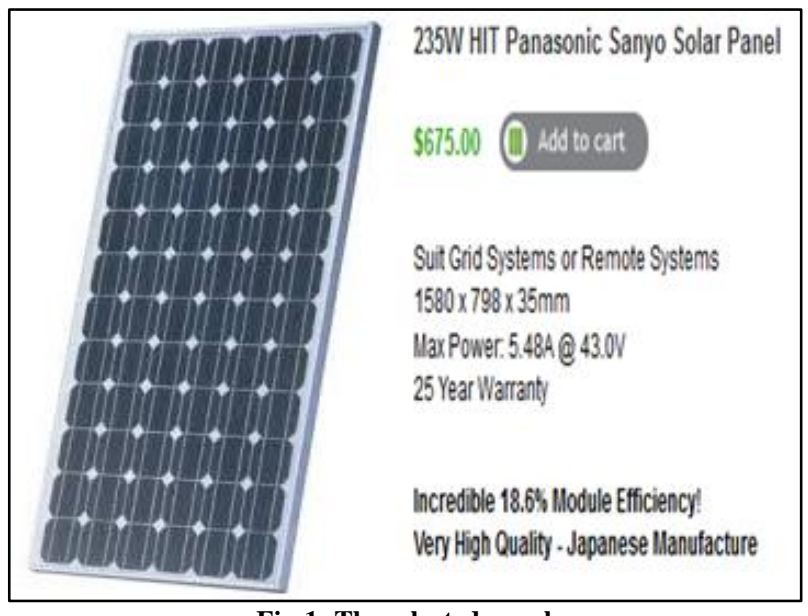

Fig-1: The selected panel

Compensate for system inefficiencies. Every part of a solar powered system has some inefficiency in it. The rule of thumb is if you are going to use an inverter (to produce AC) your total system inefficiency will be $30 \%$. For systems that will be using the DC voltage directly from the battery bank, the inefficiency factor is $20 \%$. So, to compensate for inefficiencies multiply your answer to step 3 by 1.3 (or 1.2 , if there's no inverter). This answer is the number of watts of solar panels you will need to provide enough electricity for your loads.
$($ Solar Panels Watts Needed for AC)(1.3) $=9440 \mathrm{~W}$

(Solar Panels Watts needed for DC loads)(1.2) $=1010$

Total Solar Panel Watts Needed $=10450 \mathrm{~W}$

Finally, to determine how many solar panels you will need, take your answer from step 4 and divide it by the rated power output (watts) of the solar panel that you have chosen.

Total Solar Panels Needed $=($ Total Solar Panel Watts Needed $) /($ Solar Panel Rated output $)$ Total Solar Panels Needed $=(10450) / 235$ Watts $=45$ Panels

\section{Because}

- The number of panels needed (45panels)for this house is very high and the power needed also is very large(55.435KW.hr/day)

- $\quad$ There are losses in the battery and the converter

So we need amount of power generated more than $55.435 \mathrm{KW} . \mathrm{hr} / \mathrm{day}$

Watts needed for $\mathrm{AC}=49.675 \mathrm{X} 1.3=64.577 \mathrm{KW} . \mathrm{hr} /$ day

Watts needed for DC=5.760X1.2=6.912KW.hr/day

The total watts needed for the home $=64.577+6.912=71.489 \mathrm{KW} . \mathrm{hr} /$ day 


\section{Important decision}

Due to the large number of solar panels required and the resulting large cost, it is possible to use wind power equipment for the desired home as shown in Figure 2.

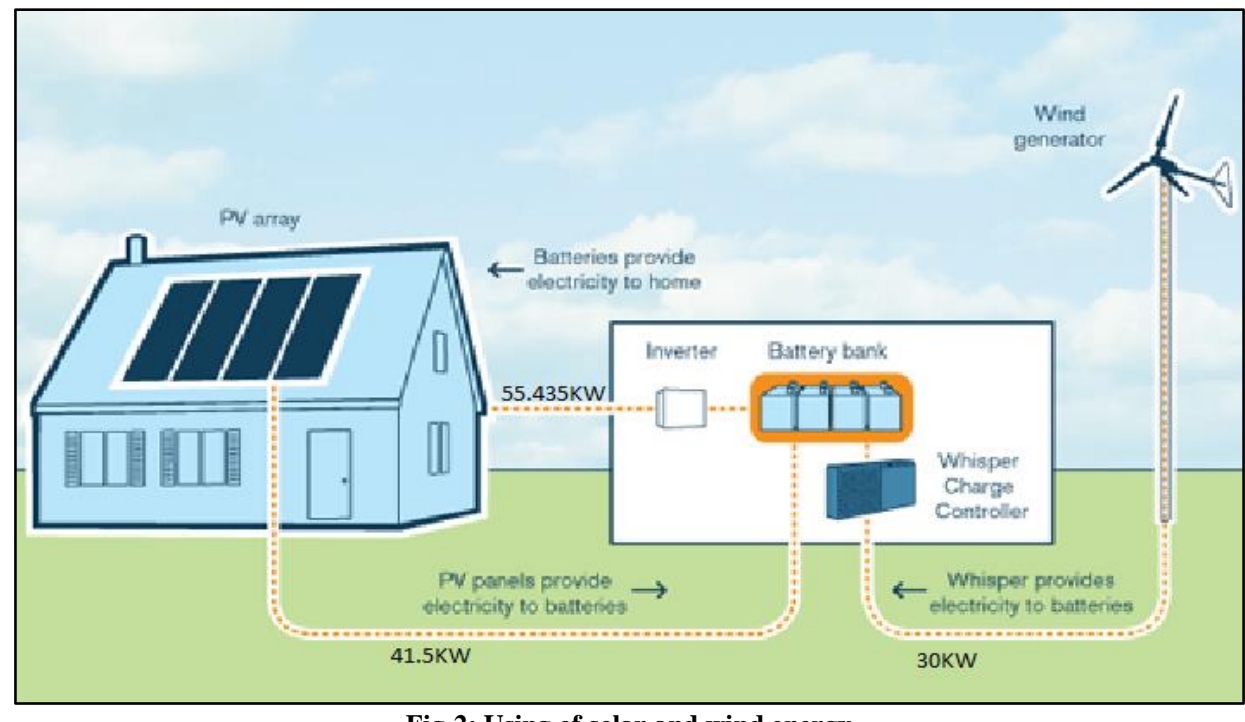

Fig-2: Using of solar and wind energy

By using 41500W.hr per day, we can find the number of panels needed:

Solar Panel Watts needed: (Total Watt- hr. /day)/(full sun hours/day)

Total Solar panels watts needed $=41500 / 6.84=6067 \mathrm{~W}$

Total Solar Panels Needed $=6067 / 235$ Watts $=26$ Panels

\section{Wind energy in Libya}

Wind energy was utilized for water pumping in many cases since 1940. The use of this energy has not been developed extensively because the wind-mills need some maintenance from time to time. In 2004 measurements of the wind speed statistics has been conducted and showed that there is a high potentiality for wind energy in Libya. The average wind speed at a 40 meter height is between $6-7.5 \mathrm{~m} / \mathrm{s}$. Figure 3 shows the average wind speed measured in different locations of the Libyan coast area.
The use of wind energy for electricity production has not been started yet in Libya, but a project was contracted for installing $25 \mathrm{MW}$ as a pilot project to be erected in two years' time. A project to prepare two Atlas that provide fast access to reliable solar and wind data throughout Libya is also been contracted for. The Atlas will allow for accurate analysis of the available wind and solar resources anywhere in Libya, and will be therefore very important for planning profitable wind farms and solar projects.

Figure 3 shows the average wind speed in some Libyan cities in meter per second.

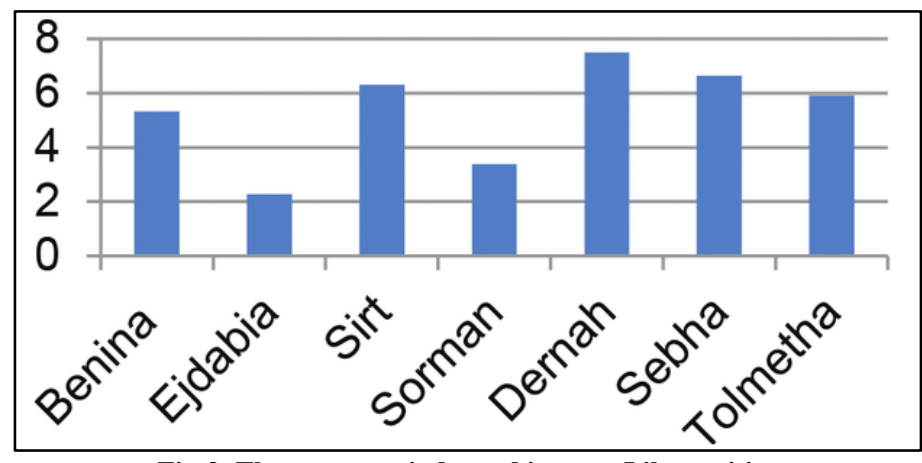

Fig-3: The average wind speed in some Libyan cities

\section{Wind energy calculation}

Wind power depends on air density, rotor diameter, and the air velocity as shown in the following figure: 


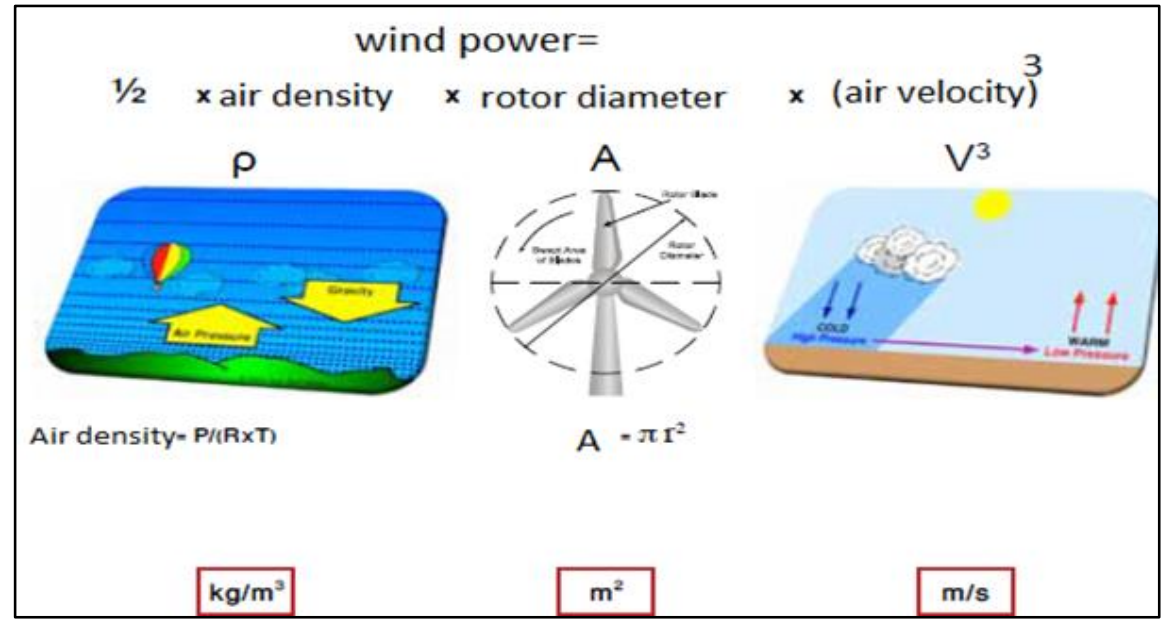

Fig-4: Wind energy calculation

Calculation of Mean monthly wind speed $(\mathrm{m} / \mathrm{s})$ for Bani Walid city: Table 4 shows the average wind speed for each month due to several years in the Libyan city of Bani Walid.

Table-4: The average wind speed in Bani Walid city

\begin{tabular}{|l|l|l|l|l|l|l|l|l|l|l|}
\hline Year & $\mathbf{2 0 0 9}$ & $\mathbf{2 0 1 0}$ & $\mathbf{2 0 1 1}$ & $\mathbf{2 0 1 2}$ & $\mathbf{2 0 1 3}$ & $\mathbf{2 0 1 4}$ & $\mathbf{2 0 1 5}$ & $\mathbf{2 0 1 6}$ & $\mathbf{2 0 1 7}$ & $\mathbf{2 0 1 8}$ \\
\hline January & 5.71 & 6.44 & 5.92 & 8.34 & 6.76 & 6.42 & 6.5 & 5.48 & 6.44 & 4.92 \\
\hline February & 6.78 & 5.73 & 5.1 & 7.55 & 6.57 & 5.76 & 6.22 & 6.33 & 8.39 & 5.38 \\
\hline March & 6.46 & 6.25 & 6.64 & 6.2 & 6.97 & 8.75 & 7.26 & 4.87 & 5.71 & 6.37 \\
\hline April & 6.31 & 6.93 & 7.25 & 8.01 & 8.03 & 6.62 & 6.5 & 6.06 & 6.08 & 5.38 \\
\hline May & 6.66 & 5.75 & 6.45 & 5.89 & 8.1 & 7.71 & 6.26 & 5.43 & 5.87 & 5.46 \\
\hline June & 6.24 & 6.33 & 6.8 & 4.86 & 6.94 & 6.96 & 6.52 & 5.22 & 4.7 & 4.6 \\
\hline July & 6.41 & 4.29 & 5.65 & 5.48 & 7.12 & 5.24 & 6.36 & 4.5 & 4.03 & 4.93 \\
\hline August & 5.16 & 4.9 & 6.9 & 4.7 & 6.47 & 4.73 & 6.57 & 3.7 & 4.00 & 5.38 \\
\hline September & 7.17 & 6.25 & 8.03 & 5.38 & 6.28 & 5.67 & 6.68 & 4.89 & 5.74 & 4.8 \\
\hline October & 6.65 & 5.58 & 8.37 & 5.36 & 6.02 & 5.97 & 6.73 & 5.4 & 4.02 & 4.45 \\
\hline November & 5.56 & 4.97 & 7.37 & 6.26 & 5.82 & 5.27 & 6.9 & 4.42 & 6.45 & 6.18 \\
\hline December & 4.61 & 4.87 & 7.54 & 6.79 & 5.9 & 5.56 & 7.49 & 5.79 & 6.99 & 6.74 \\
\hline
\end{tabular}

\section{To determine the suitable rotor diameter}

- From last table, Mean monthly wind speed $(\mathrm{m} / \mathrm{s})$ for Bani Walid city in ten years from 2009 to 2018 is $6.1 \mathrm{~m} / \mathrm{s}$

A Air density $=1.22 \mathrm{Kg} / \mathrm{m}^{3}$

口 Power needed $=30000 \mathrm{~W} \cdot \mathrm{hr} / \mathrm{day}=(30000 / 24)=1250 \mathrm{~W}$

\section{From the last equation}

\section{$\underline{\text { Rotor diameter }=3.4 \mathrm{~m}}$}

\section{Battery sizing calculation}

The first thing you have to decide on is if you are going to use a $12 \mathrm{~V}, 24 \mathrm{~V}$ or $48 \mathrm{~V}$ DC system (these are the most common selections). The advantages to using a larger DC voltage system is that the wires/cabling you will need to use can be of a smaller gauge (smaller diameter). Systems with higher DC voltages lose less energy due to resistances in wiring that those of lower DC voltage (e.g. 12V).

An advantage to $12 \mathrm{~V}$ system is that it's a bit easier to find equipment you can power directly off of the batteries (i.e. $12 \mathrm{~V}$ ). Whereas if you were to power
$12 \mathrm{~V}$ appliances off of a $48 \mathrm{~V}$ system, you would need to also buy a DC voltage converter.

Determine the total watt hours you will be using per day (in this project 55435W.hr).

Determine how many rainy days you might have in a row. This is the number of days that your solar panels might not be producing electricity in a row and will need to rely solely on your batteries for electricity during this time. (Typically, 3 to 7 days is used for homes and 7 to 14 for industrial purposes - like remote Telecommunications sites).

Multiply the number of watt*hours from your load calculation (Step 2) by the number of storage days (Step 3). (55435W-h)*3 =166305W.hr

Determine how deeply you want to discharge your batteries. $80 \%$ is considered the maximum amount you can discharge your lead-acid battery array, whereas $50 \%$ is an optimal amount for battery longevity. Then divide the amount calculated in Step 4 by 0.80 or 0.50 (for instance) 166305/0.80 =207881 W.hr. 
Compensate your calculations for low battery temperatures. As your batteries get colder (such as in the winter months), they are capable of producing less current. Using the table below, multiply the value you calculated in Step 5 by the Multiplier Factor from table 5 , according to the lowest temperature you think your batteries will experience:

Table-5: Multiplier Factor from selection

\begin{tabular}{|c|c|c|}
\hline Degrees Fahrenheit & Degrees Celsius & Multiplier Factor \\
\hline $80^{\circ} \mathrm{F}$ & $26.0^{\circ} \mathrm{C}$ & 1.00 \\
\hline $70^{\circ} \mathrm{F}$ & $21.2^{\circ} \mathrm{C}$ & 1.04 \\
\hline $60^{\circ} \mathrm{F}$ & $15.6^{\circ} \mathrm{C}$ & 1.11 \\
\hline $50^{\circ} \mathrm{F}$ & $10.0^{\circ} \mathrm{C}$ & 1.19 \\
\hline $40^{\circ} \mathrm{F}$ & $4.4^{\circ} \mathrm{C}$ & 1.30 \\
\hline $30^{\circ} \mathrm{F}$ & $-1.1^{\circ} \mathrm{C}$ & 1.40 \\
\hline $20^{\circ} \mathrm{F}$ & $-6.7^{\circ} \mathrm{C}$ & 1.59 \\
\hline
\end{tabular}

The lowest temperature in Bani Walid city approximately $10^{\circ} \mathrm{C}$ (Multiplier Factor $=1.19$ ).

Total watt hours you will be using per day $=202781 \mathrm{X} 1.19=241309 \mathrm{~W} . \mathrm{hr}$

\section{Cost considerations}

When using solar panels

The price of each panel $675 \$$ Total price $=26 \times 675=17550 \$$

The price of each battery $100 \$$ Total price $=80 \times 100=8000 \$$

Total cost $=17550+8000=25550 \$$

When using wind turbine

To get $30 \mathrm{KW}$ by using wind turbine with rotor diameter $3.4 \mathrm{~m}$.it will cost $8000 \$$ (chines company).

\section{Finally}

In this project: it is better to get all energy requirements by using 2 wind turbines with $16000 \$$ total cost.

\section{CONCLUSION}

This study, entitled Renewable Energy Home Design in Bani Walid city/Libya, showed that solar energy can be used to supply the electricity to the home, but the cost will be partially high, where the total cost was $\$ 25550$. But in the case of the use wind energy in the area where the home is located, it was better to provide the home with two wind turbines with total cost of $\$ 16000$, This means it is best to use wind turbines instead solar cells at the home site.

\section{REFERENCES}

1. Jaber, S. (2013). Environmental impacts of wind energy. Journal of Clean Energy Technologies, 1(3), 251-254.

2. Abolhosseini, S., Heshmati, A., \& Altmann, J. (2014). A review of renewable energy supply and energy efficiency technologies.

3. Abdulkadr, A. M., \& Elmabrouk, A. M. (2008). Assessment of the wind energy potential on the coast of Tripoli.

4. Mohamed, A. M., Al-Habaibeh, A., Abdo, H., \& Abdunnabi, M. J. R. (2013). The significance of utilizing renewable energy options into the Libyan Energy Mix. Energy Research Journal, 4(1), 1523.

5. Libyan climatic archives, Climate Department, Libyan National Meteorological Centre (LNMC).

6. Bureau of Energy Data and Studies, LNEC. (2004). Libyan National Energy Information-sixth edition 2004.

7. The Center for Solar Energy Research and Studies, Libya, http://csers.ly/en/. 